\title{
SCIENTIFIC SUBSTANTIATION OF THE STATE LAND CADASTRE IMPROVEMENT IN UKRAINE: THEORETICAL AND METHODOLOGICAL PRINCIPLES
}

Dorosh Y., Doctor of Economics Sciences, Land Management Institute of the National Academy of Agrarian Sciences of Ukraine e-mail: landukrainenaas@gmail.com orcid: https://orcid.org/0000-0002-1764-6188

Ibatullin Sh., Doctor of Economics Sciences, corresponding member of the National Academy of Agrarian Sciences of Ukraine, e-mail: shamilibatullin@gmail.com orcid: https://orcid.org/0000-0002-4032-6182 Tarnopolskyi A., Land Management Institute of the National Academy of Agrarian Sciences of Ukraine e-mail: landukrainenaas@gmail.com orcid: https://orcid.org/0000-0001-5313-6380

Dorosh O., Doctor of Economics Sciences, professor, National University of Life and Environmental Sciences of Ukraine e-mail:dorosholgas@ukr.netorcid:https://orcid.org/0000-0003-2906-4174 Abstract.

Based on the fulfilled researches, it was found that the state land cadastre system's fullness with respect to the land cadastre objects envisaged by the legislation does not meet the modern needs, which does not allow state and local governmental bodies, individuals and legal entities to make management decisions at the appropriate levels. Two of the most difficult problems are the absence of institutions of scientific cadastre support among the cadastre institutions and the removal of territorial communities as consumers and customers of land cadastral information from the land cadastre. It is revealed that the cadastre information contains a large number of errors and inaccuracies, and its structure, organizational and legal frameworks, and information processes require significant improvement. In view of this, the authors present proposals to correct deficiencies in the functioning of the land cadastre system on the basis of complex scientific research of lands of institutions, organizations and enterprises of NAAS. These proposals include 
improvement of the methodology of the land cadastre maintenance, of the methods, rules, standards and classifiers used in land management and cadastre in current economic conditions; restoration of the state statistical report on land resources in the cadastre; development of information and analytical support for managing land resources at different levels through appropriate electronic offices; cadastre development as a basis for national geospatial data infrastructure. Particular attention is paid to the application of scientific principles in conducting the land cadastre (completeness, mirror image, trust, insurance, continuity, consent, publicity) in the light of world trends.

Keywords: state land cadastre, scientific substantiation, principles, methodology of land cadastre management, mistakes, inaccuracies

Actuality. The effectiveness of managerial decision-making regarding the regulation of land relations in Ukraine, the organization of rational use and protection of land resources, the implementation of land management, the conduct of land valuation activities, the formation and maintenance of town planning cadastre and other cadastres of natural resources as well as payment for land are entirely related to the availability to the state authorities and bodies of local government, individuals and legal entities of a complete, reliable (legally motivated) information and analytical software. Such information resource should be contained in the unified system of land information according to the current legislation of Ukraine - in the State Land Cadastre. Such information and analytical support should also be made available to territorial communities, business structures, investors, scientific institutions.

The holder of the State Land Cadastre of Ukraine is the central executive body implementing state policy in the field of land relations - the State Service of Ukraine for Geodesy, Cartography and Cadastre, and its administrator is the state enterprise "Center of State Land Cadastre", which belongs to the sphere of management of this service. However, there are no cadastre institutions for the scientific support of land cadastre and territorial communities (as consumers and customers of land cadastral 
information are not involved in the land cadastre), which would significantly improve the process of filling this registration system.

Article 1 of the Law of Ukraine "On the State Land Cadastre" defines that "State land cadastre is the only state geoinformation system, containing data on lands located within the state borders of Ukraine, their purpose, restrictions in their use, as well as data on quantitative and qualitative characteristics of land, their assessment, of the distribution of land between owners and users" [1].

According to the law, the objects of the State Land Cadastre are defined as: 1) lands within the state borders of Ukraine; 2) lands within the territory of the administrative-territorial units; 3) land use restrictions; 4) land plots.

Since 2013, the land cadastre in Ukraine is maintained on a modern information technology platform, the important elements of which are made available to the public in the form of a public cadastral map. The system is based on an open source software. The platform includes hundreds of geospatial and attribution modules and objects such as Web, GIS, WMS, NSDI, relational databases, geoserver, analytics, spatial modeling and more. The cadastral system has a modern, extremely high level of protection of information and information processes from the organizational and software point of view. Since its launch, it has registered tens of millions of lands and changes to it. The system currently handles over one million requests per day.

The national cadastral system interface is constantly being improved, acquiring new tools and useful features. The system exchanges data between the land cadastre and the state register of corporeal rights to real estate. Currently, the list and content of electronic information services of the cadastral system is being expanded and improved. A separate module of the system is the regulatory and monetary assessment of agricultural land.

However, the formation of the Ukrainian cadastre cannot be considered complete, since it does not contain information about all land plots and lands of the State, the cadastre data contains a large number of errors and inaccuracies, and its 
structure, legal framework and information processes require significant improvement.

\section{Analysis of recent researches and publications.}

Researchers from the Land Management Institute of the National Academy of Sciences of Ukraine conducted research, the results of which found that the land cadastre, currently being conducted in Ukraine, has a number of significant shortcomings and needs improvement in light of scientific substantiation and use of the best world experience. The above gives grounds for the relevance and validity of the research.

Although these issues are problematized in the works of Ukrainian scientists and in the publications of civil activists, the background and sequence of eliminating the problems related to the current land cadastre system in Ukraine and making proposals for its improvement have not been fully explored.

The purpose of the research is to investigate the theoretical and methodological principles of the formation and maintenance of the State Land Cadastre in Ukraine, to assess its compliance with modern needs.

Results and discussion. The Law of Ukraine "On the State Land Cadastre" (Article 3) defines the principles of maintaining the land cadastre, which include: the obligation to include information about all its objects in this system; ensuring the objectivity, reliability and completeness of this information; compliance with the law when entering, receiving, distributing and storing information; openness and accessibility of information; continuity of entering information about the objects of the State Land Cadastre, which are changing; information on the objects of the State Land Cadastre, which are changing and documentation of all information (Article 3).

From a scientific point of view, we believe that these principles should be supplemented by scientific principles of land cadastre, the compliance with which is important to achieve: completeness, mirror image, trust, insurance, continuity, consent, publicity $[2,3]$. These principles are formed by us in the light of world trends 
and can serve as a basis for further scientific support of the land cadastre of Ukraine (Fig. 1).
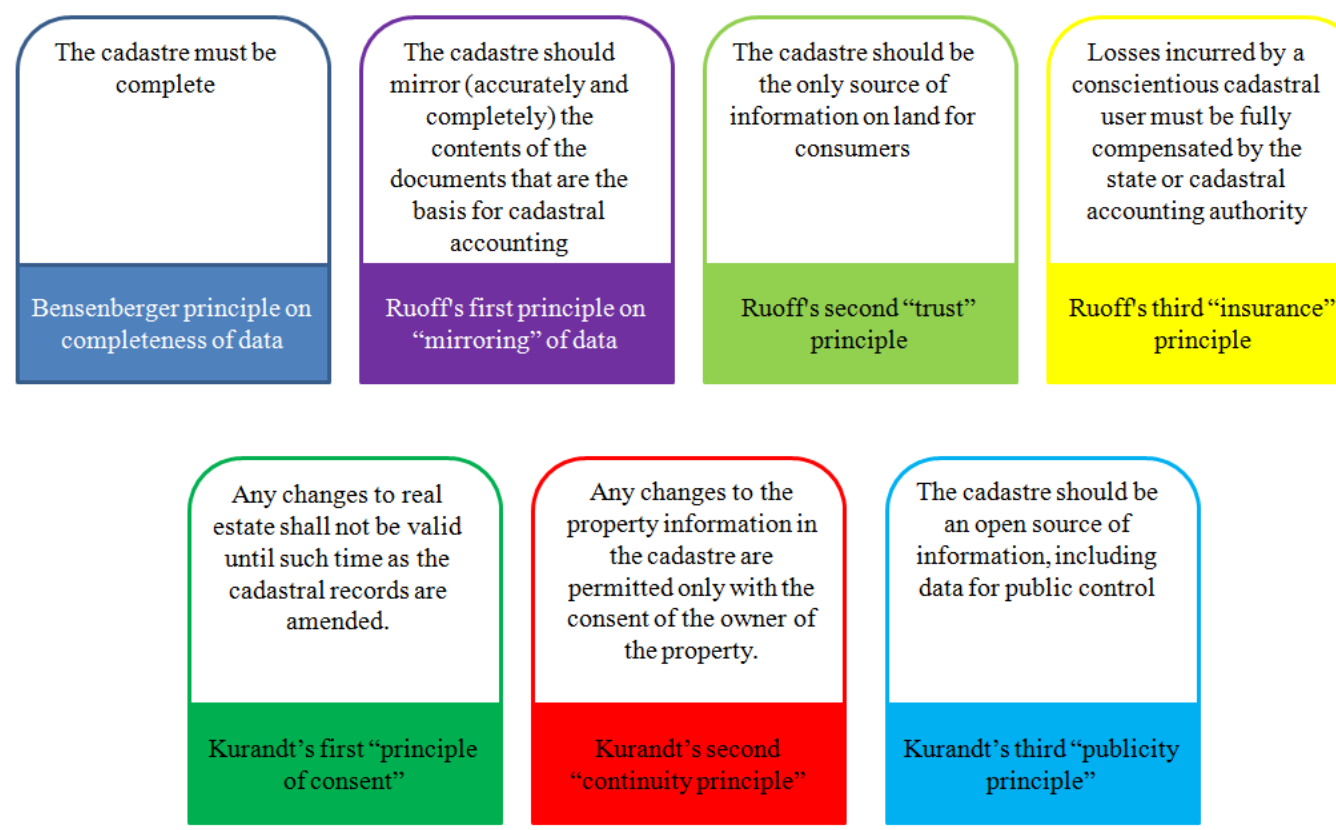

Figure 1. Proposals for the principles of land cadastre in Ukraine, formed in the light of global trends.

Thus, according to the Bensenberger principle [4], "the cadastre remains useless until it is completed for a specific geographical area". Therefore, the cadastre must be complete. That is, regardless of the nature of the terrain, it must provide a comprehensive description of all the land in each region. The law of Ukraine defines the claimant principle of cadastre functioning, therefore a considerable part of the land remains not covered by the cadastre.

According to the Ruoff's principle [5], the cadastre should mirror the contents of the documents that are the basis for cadastral registration. Although the Ukrainian cadastre has high-tech information integration with other state registers, including the state register of corporeal rights to real estate, the priority remains with the paper source legal documents. For example, the cadastre does not include about 4 million land plots, state acts on which had been issued by 2013 without cadastral numbers. Also, about 1.5 million ha of land of collective ownership remain unregistered in the cadastre. 
Obviously, the opposite principle must be observed as well - the only information with the official status should be entered in the cadastre. Recently, this principle has been violated by the government of the country, since a number of noncore and informal data and background layers, not supported by legal documents and therefore not legitimate, have been added to the cadastral map,

The cadastre must be provided with an appropriate geodetic and current mapping basis. These are, in particular, orthophotos that were created during the years of 2005 - 2011 and are now out of date because they are considered obsolete and unreliable (with an update period of not more than five years).

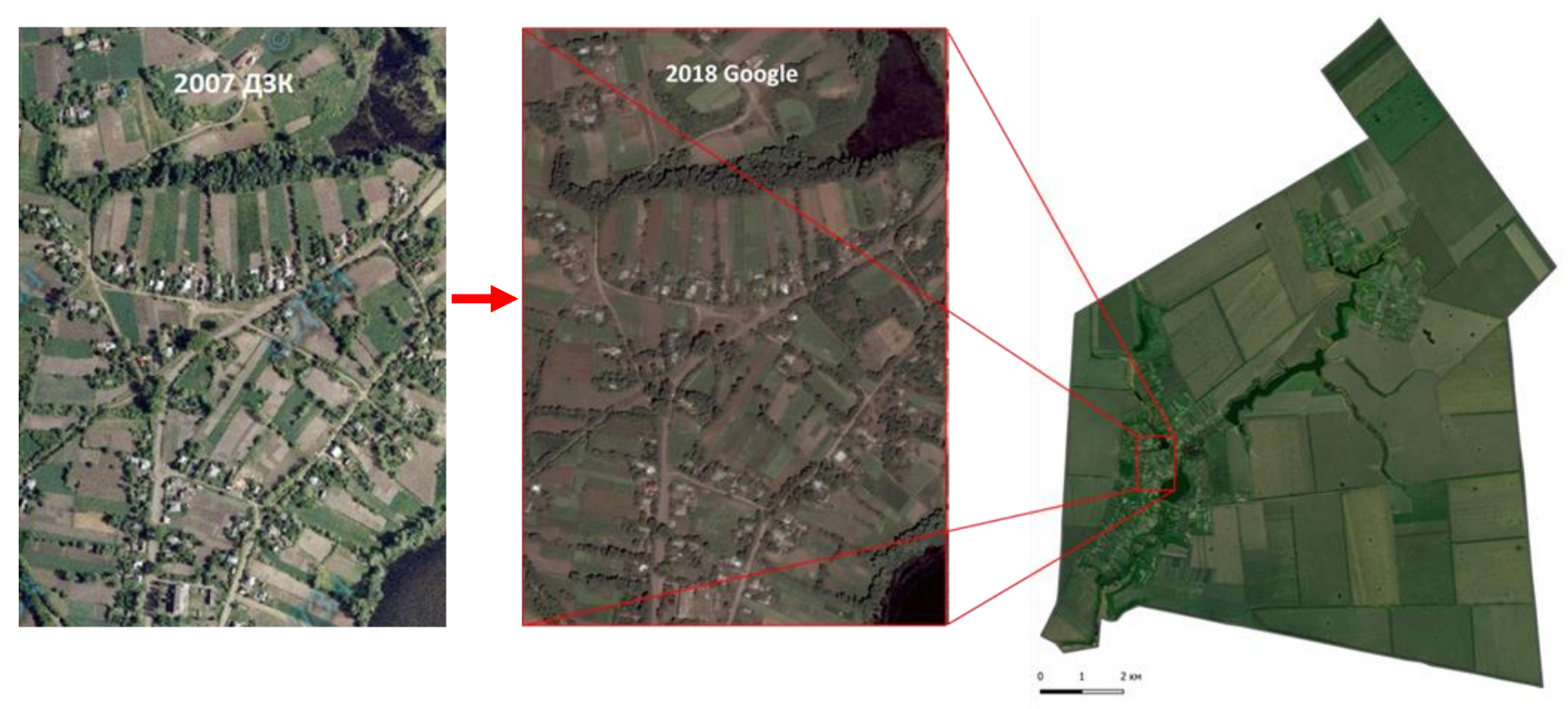

Fig. 2. Orthophotos on the example of the Demkivsky village council of Drabiv district of Cherkasy oblast.

In accordance with the principle of trust (Ruoff's second principle), the cadastre should serve as the sole source of information on land plots for consumers, and it should not be questioned whether the cadastre data is reliable. In current Ukrainian conditions, the cadastre can be the only source of up-to-date information about all objects of cadastral accounting. However, the level of trust in a cadastre decreases due to the large number of errors and inconsistencies in its inventory, and they have not been corrected for many years. This principle is violated by the presence of the following errors: topological, logical and semantic [5]. 
Topological errors include: self-intersection of boundaries of land plots, their complete or partial duplication, displacement of all or some of their points, their overlapping or breaks, errors in the coordinate system and others (Fig. 3).

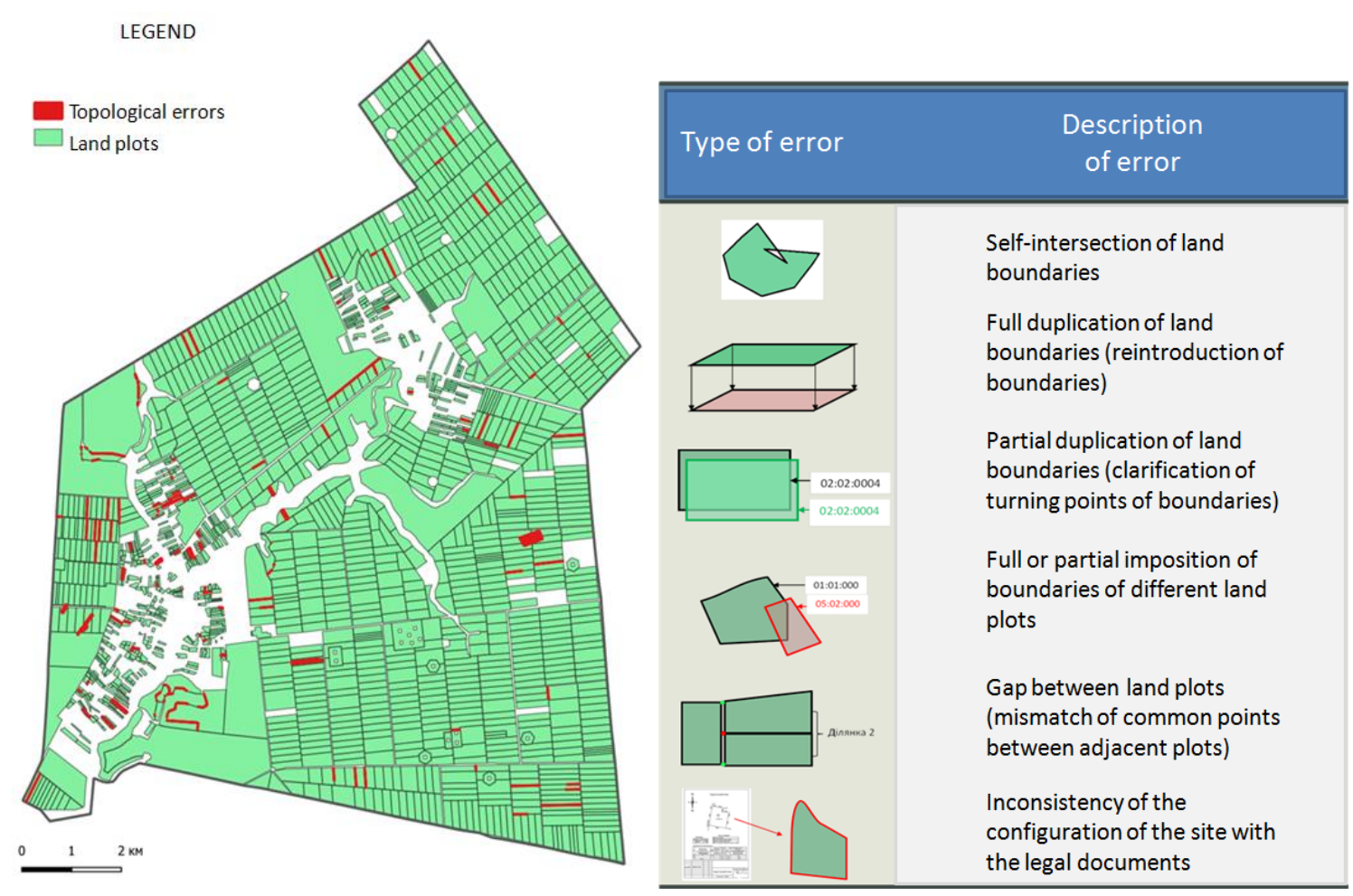

Fig. 3. Topological errors in the cadastre on the example of the Demkivsky village council of Drabiv district of Cherkasy oblast.

Logical errors in the cadastre can be attributed to errors in the coding of cadastral numbers, zones, quarters, purpose, ownership, etc. (Fig. 4). 

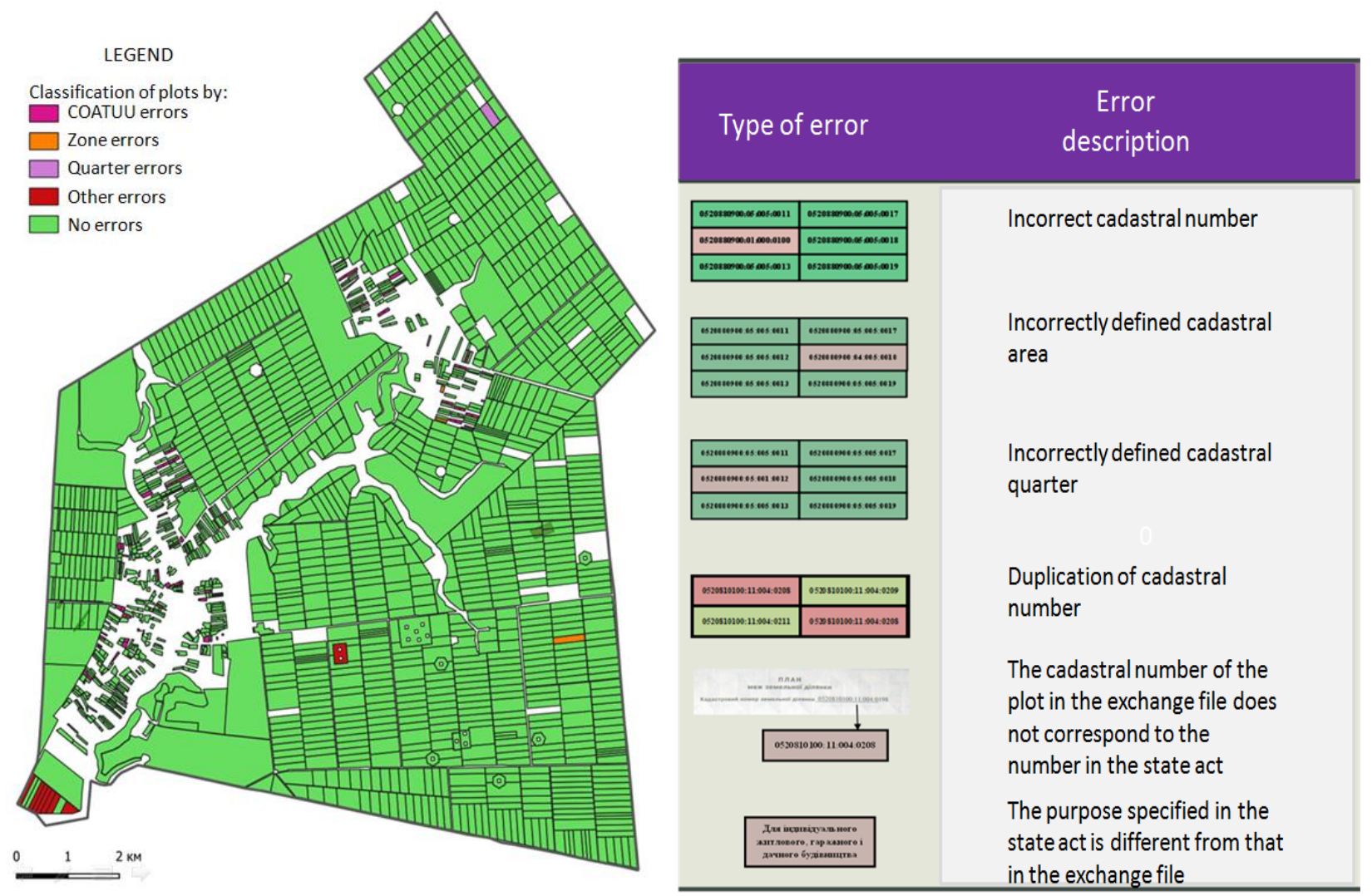

Fig. 4. Logical errors in the cadastre on the example of the Demkivsky village council of Drabiv district of Cherkasy region.

Semantic errors include, for example, the situation when the area of the land in the exchange file does not correspond to the area of the land provided by the documentation on land management.

According to the insurance principle (Ruoff's third principle) [5], any losses incurred by a diligent user of cadastral information as a result of trust in the cadastre, which in fact proved to be unreliable, must be fully compensated by the state or the cadastral accounting authority. There are no such compensations provided by the legislation of Ukraine.

According to the Kurandt principle [4], any changes to the property in the cadastre are permitted only with the consent of the owner of the property. Although, this "principle of consent" is directly established by Ukrainian law, since 2015, the directive of the central executive body on land resources has opened land registration books without the knowledge of the owners, which led to an artificial increase in errors in the information of millions of land. 
The continuity principle (another Kurandt principle) [3] states that any changes to real estate shall not be valid until the relevant data is added to the cadastre. At present, the division, consolidation, redistribution, allocation or refinement of land boundaries in Ukraine becomes valid only if the cadastre is amended accordingly. However, from the procedural point of view, the processes of land registration and the establishment of legally significant material rights to them are torn between the registration and cadastral systems. The latter is technical in terms of legal relations.

The boundaries of the territories of the administrative-territorial units of Ukraine are determined among the objects of the state land cadastre. However, the current legislation does not provide the cadastre with the boundaries of united territorial communities and territories of village councils. The number of settlements is insignificant, the limits of which are reflected in the land cadastre (about $5 \%$ ), which complicates the exercise of power by local governmental bodies. And those boundaries of the administrative-territorial units, entered in the cadaster, often contain errors, cross the boundaries of land, cadastral quarters and mode-forming objects. Information about agricultural land areas and land of administrative and territorial units, provided by the Law, are also missing from the cadastre.

Moreover, the cadastre boundaries of regions and districts do not always coincide with the boundaries defined by the map of the administrative and territorial structure of Ukraine maintained with the participation of the Ministry of Regional Development.

An important component of the land cadastre is the set of classifiers and directories that characterize certain legal, economic, social and spatial aspects of land. Such classifiers include: land categories, types of purpose, types of land use and others.

However, there are a number of problems in the cadastre due to repeated changes, inconsistencies and insufficient detail of such classifiers. For example, current classifiers do not have identifiers for part of the lands of scientific institutions, enterprises and organizations, such as: research fields, demonstration sites, buffer 
zones, etc. Today, it is impossible to analyze land within and outside settlements in an automated way.

The lack of mechanisms for correcting errors in the classifiers has led to the fact that the cadastre currently contains more than 50 thousand unique types of land use instead of 120 types stipulated by the order of the State Land Committee of Ukraine.

In today's market conditions, this has certain legal risks and has a negative impact on the economic development of the territories. Therefore, it is necessary to develop new, more sophisticated classifiers, including types of land use. The concept of types of land use, which currently has almost no meaningful load in the cadastre, requires separate research and methodological development.

The drawback of the legislation on the State Land Cadastre, in our opinion, is the fundamental absence, among its objects, of land and land use boundaries. For example, the cadastral map does not identify any land owned or used by a particular individual or entity. Of course, this information is debatable in terms of personal data protection. But it is important for the authorized user to have complete information on their own objects.

The analysis we conducted for the Demkivsky village council of Drabiv district of Cherkasy oblast indicates that agricultural land use is not optimally formed in it; there is a discrepancy among the registered rights to the actual use of land (Fig. 5). 


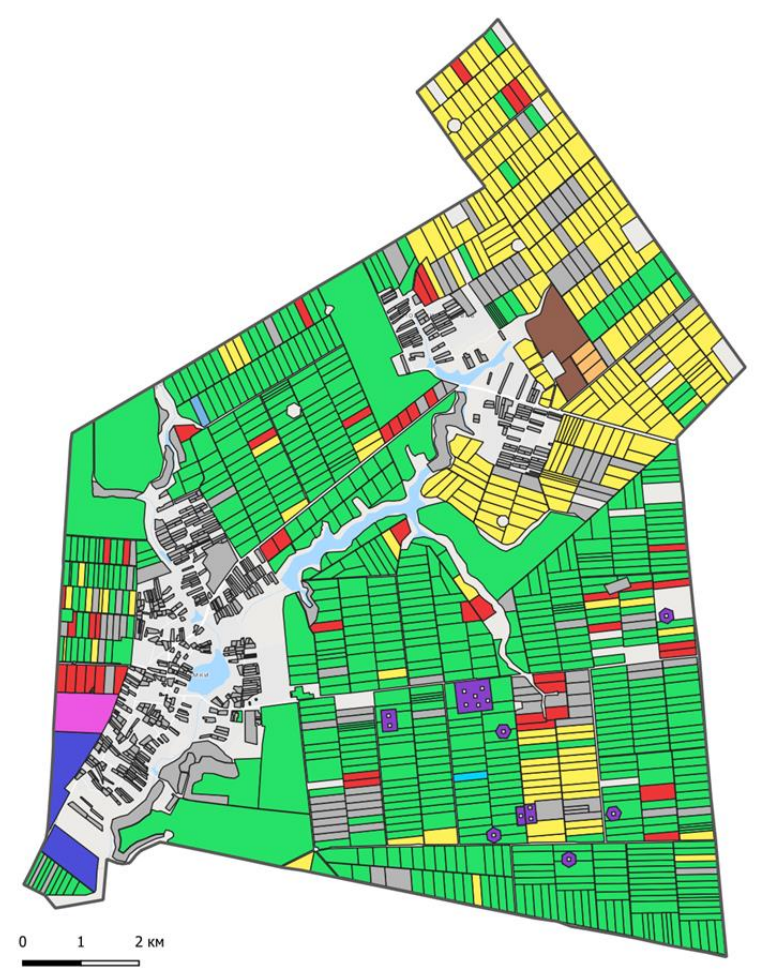

Fig. 5. Agricultural land use, based on secondary law, on the example of the Demkivsky village council of Drabiv district of Cherkasy region.

There are so-called annual "land plots exchanges", which are often not documented. This is explained by the fact that one agro-holding, on an oral contractual basis, actually processes land leased by another agro-holding within the land. And vice versa. This leads to potential risks and transaction losses (such as raider hijacking, fraudulent schemes, speculation).

There is a need in the agricultural producers' management system to reflect the state of agricultural production and economic use, which is not the object of the land cadastre. However, such information is extremely important for management decisions in the field of agricultural production at different levels of the hierarchy of government and corporate governance.

First, it shows the spatial location of crops, the extent of their concentration, and the level of ignoring the scientific principles of cultivation. Please note that despite the large number of landownings, in fact, only a limited number of exportoriented crops is cultivated on large land areas without considering the principles of crop rotation and agri-environmental restrictions. 
Secondly, comparing the boundaries of actual land under use with the boundaries of registered property rights is an important source for management and control in land relations. Figure 6 shows the missing areas in the cadastre that are being processed. Areas, displayed in the cadastre but processed without registered leases, are also listed. If for land plots, such use can be explained by cadastre errors, and requires additional identification, then for state and communal land, so-called "self-seizure" is subject to careful checks by the relevant controlling bodies.

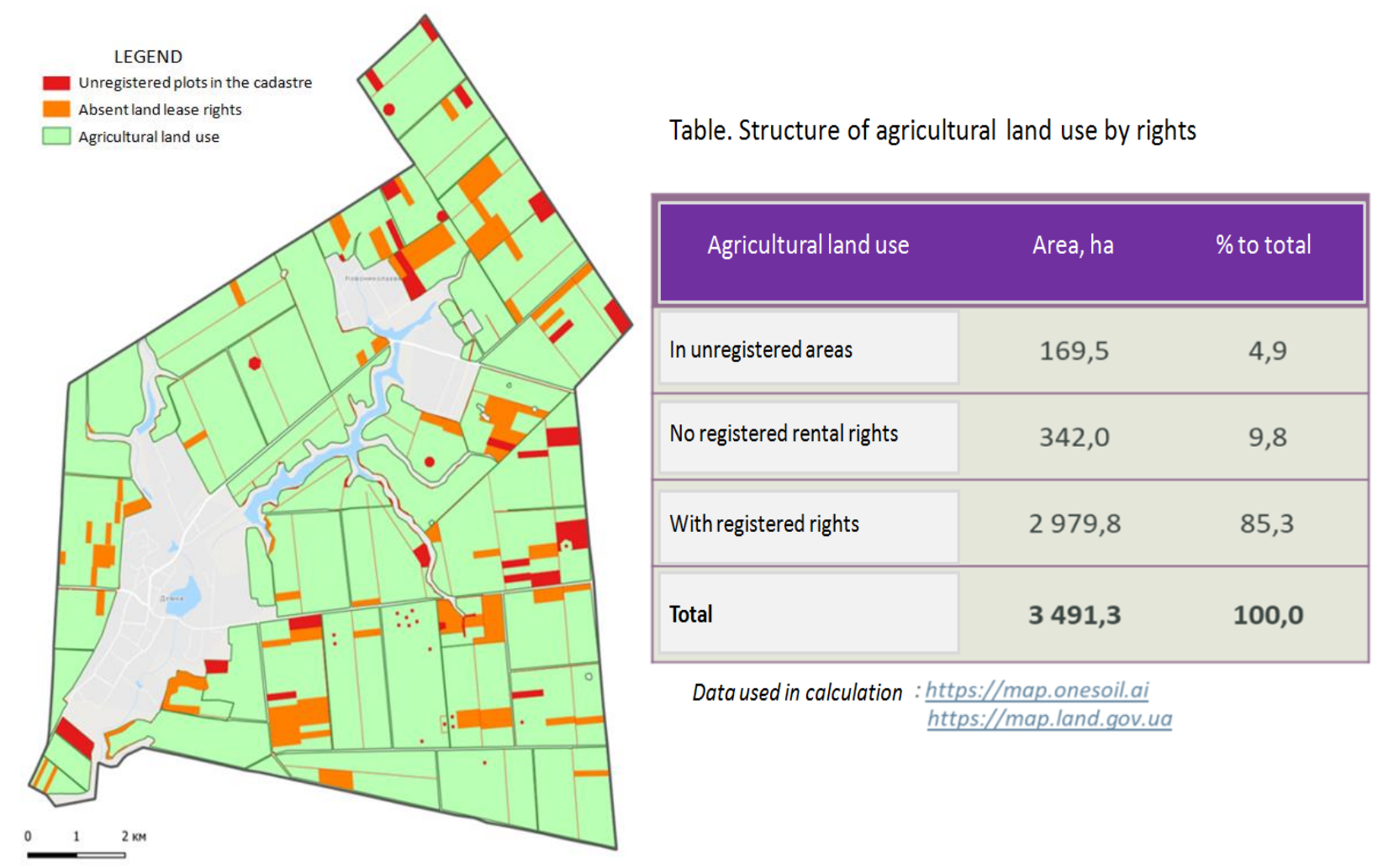

Fig. 6. Absence of rights to use agricultural land on the example of the Demkivsky village council of Drabiv district of Cherkasy oblast.

In this respect, a wide range of zones and boundaries of restrictions, encumbrances, land easements, boundaries of other rights that collectively determine the legal regime of land uses should be formed in the land cadastre. The institutionalization of land relations in this way will allow the formation of a legal regime that will be optimal both in terms of economic efficiency and in terms of sustainable rural development.

Despite the fact that the legislation states the need for cadastral registration of limits of land use restrictions, such objects consist approximately $1-2 \%$ in the 
cadastre. The lack of institutionalization of restrictions can lead to high direct and indirect risks for buyers and territorial communities in the implementation of the agricultural land market.

Ignoring the agrarian science has led to a number of shortcomings in the functioning of the land cadastre. The information and analytical support of the cadastre regarding the qualitative characteristics of land, including their types, agricultural production groups of soils, erodedness, the need for conservation and implementation of other measures for the protection of land, is insufficient for managerial purposes. The work, aimed to create a digital terrain model in the cadastre as a land protection information platform and anti-erosion measures, has not been completed.

The current land cadastre does not contain information for comprehension of the transformation processes taking place in both socio-economic and physicalgeographical spaces. Just imagine the extent of this problemToday we do not know exactly how the plowing of farmland is changing, how urbanization, selfafforestation, climate change, rural depopulation affect the transformation of land. What is the dynamics of commercial and industrial development of land by types of economic activity and forms of management? This cadastre problem is exacerbated by the actual elimination of national statistical reporting on land, which was previously conducted in the "6-zem" form.

The National Academy of Agrarian Sciences of Ukraine is one of the largest land users of state-owned lands, the information on which must be entered in the state land cadastre. However, according to our research, less than a half of the lands of NAAS institutions, enterprises and organizations are registered in the land cadastre. In this case, even the information on the registered land plots contain a large number of errors in the types of intended use, forms of ownership, areas, rights. This situation leads to significant risks of losses and inefficient use of state-owned land.

Conclusions. Scientists at the Land Management Institute of the National Academy of Sciences of Ukraine see the possibility of correcting deficiencies in the 
functioning of the land cadastre by carrying out complex scientific researches and further introduction of their results. Such proposals are currently being worked out on the basis of the lands of NAAS institutions, organizations and enterprises.

Further improvement of the land cadastre system in Ukraine should proceed from the need to solve the following problems:

- improvement of the methodology of land cadastre management, methods, rules, standards, classifiers used in land management and cadastre in modern economic conditions;

- $\quad$ improving the quality of the State Land Cadastre data, including updating its geodetic and mapping bases, updating orthophoto maps;

- $\quad$ error correction in both spatial and attribute data and in data updating procedures;

- $\quad$ ensuring the processes of filling the land cadastre data;

- $\quad$ updating of cadastre classifiers and directories;

- improving digital processes and optimizing them, including the further development of electronic cadastre services;

- restoration of the state statistical report on land resources in the cadastre;

- development of information and analytical support for land management at different levels (e.g. by hierarchy, state - region - district - local government economic entities - citizens) through appropriate electronic offices;

- $\quad$ ensuring self-financing and payback of services of the state land cadastre;

- development of the cadastre as the basis for national geospatial data infrastructure;

- harmonization of state information systems and cadastres with each other;

- preparation of a cadastre for information and analytical support for the development and regulation of the agricultural land market (market monitoring system).

Thus, it is necessary to focus on the future in improving the land cadastre. This applies to both the technical aspects and the fundamental principles of the system. It 
is important to conceptually adhere the focus of the Ukrainian cadastre on multipurpose use, automation, service integration, geocoding and transformation of the country's digital space. 


\section{REFERENCES}

1. Law of Ukraine "On State Land Cadastre" № 3613-VI (2020). Available at: https://zakon.rada.gov.ua/laws/show/3613-17

2. Karpik A.P., Vetoshkin D.N., Arkhipenko O.P. (2012). Analiz sovremennogo sostoyaniya gosudarstvennogo kadastra nedvizhimosti v Rossii [Analysis of the current state of the state real estate cadastre in Russia]. Interekspo GeoSibir, 7, 3-11.

3. Klyushnichenko V.N. (2017). Analiz princzipov vedeniya kadastra na sovremennom etape [Analysis of the principles of cadastre management at the present stage]. Geodeziya i kartografiya, 6, 43-48.

4. Rowton Simpson A. (1976) Land Law and Registration. Cambridge University Press, Gt Britain, 726 p.

5. Zevenbergen J. (2002) Systems of Land Registration. Aspects and Effects, Nederlandse Commissie voor Geodesie Netherlands Geodetic Commission, Delft. Available at: http://www.ncgeo.nl/downloads/51Zevenbergen.pdf

Дорош Й.М., Ібатуллін Ш.І., Тарнопольський А.В., Дорош О.С.

НАУКОВЕ ОБГРУНТУВАННЯ УДОСКОНАЛЕННЯ СИСТЕМИ ДЕРЖАВНОГО ЗЕМЕЛЬНОГО КАДАСТРУ В УКРАЇНІ: ТЕОРЕТИЧНІ ТА МЕТОДОЛОГІЧНІ ЗАСАДИ

Аннотація. На підставі проведених досліджень з'ясовано, що наповненість системи Державного земельного кадастру стосовно передбачених чинним законодавством об'єктів земельного кадастру не відповідає сучасним потребам, щчо не дозволяє органам державної влади та органам місцевого самоврядування, фізичним та юридичним особам здійснювати управлінські рімення на відповідних рівнях. Однією із визначальних проблем є те, щуо серед інституцій кадастру відсутні установи з наукового забезпечення ведення земельного кадастру та відсторонення територіальних громад як споживачів та замовників земельнокадастрової інформаџї від ведення земельного кадастру. Виявлено, щуо у відомостях кадастру міститься велика кількість помилок $i$ неточностей, а його структура, організаційно-правові засади та інформаційні процеси потребують суттєвого удосконалення. 3 огляду на це, авторами наведені пропозищіі з виправлення недоліків у 
функиіонуванні системи земельного кадастру на підставі проведення комплексних наукових досліджень на базі земель установ, організащій та підприємств НААН, серед яких пріоритетну позицію займають: удосконалення методологї ведення земельного кадастру, методик, правил, стандартів, класифікаторів, які використовуються у землеустрої та кадастрі у сучасних економічних умовах; відновлення державної статистичної звітності з земельних ресурсів у складі кадастру; розвиток інформаційно-аналітичного забезпечення управління земельними ресурсами на різних рівнях через відповідні електронні кабінети; розвиток кадастру як основи нащіональної інфраструктури геопросторових даних. Особливу увагу приділено застосуванню наукових принципів у веденні земельного кадастру (завершеності, дзеркальності, довіри, страхування, безперервності, згоди, публічності) з урахуванням світових трендів.

Ключові слова: державний земельний кадастр, наукове обтрунтування, принципи, методологія ведення земельного кадастру, помилки, неточності

Дорош И.М., Ибатуллин Ш.И., Тарнопольский А.В., Дорош О.С.

\section{НАУЧНОЕ ОБОСНОВАНИЕ СОВЕРШЕНСТВОВАНИЯ СИСТЕМЫ ГОСУДАРСТВЕННОГО ЗЕМЕЛЬНОГО КАДАСТРА В УКРАИНЕ: ТЕОРЕТИЧЕСКИЕ И МЕТОДОЛОГИЧЕСКИЕ ОСНОВЫ}

На основании проведенных исследований установлено, что наполненность системы Государственного земельного кадастра относительно предусмотренных действующим законодательством объектов земельного кадастра не соответствует современным потребностям, что не позволяет органам государственной власти и органам местного самоуправления, физическим и юридическим лицам осуществлять управленческие решения на соответствующих уровнях. Одним из главных проблем является то, что среди институтов кадастра отсутствуют учреждения по научному обеспечению ведения земельного кадастра и отстранения территориальных общин как потребителей и заказчиков земельно-кадастровой информачии от ведения земельного кадастра. Выявлено, что в сведениях кадастра содержится большое количество ошибок и неточностей, а его структура, организационноправовые основы и информачионные процессы требуют существенного 
усовершенствования. Учитьввая это, авторами приведены предложения по исправлению недостатков в функиионировании системь земельного кадастра на основании проведения комплексных научных исследований на базе земель учреждений, организаций и предприятий НААН, среди которых приоритетную позицию занимают: совершенствование методологии ведения земельного кадастра, методик, правил, стандартов, классификаторов, используемьх в землеустройстве и кадастре в современных экономических условиях; восстановление государственной статистической отчетности по земельным ресурсам в составе кадастра развитие информационно-аналитического обеспечения управления земельными ресурсами на разных уровнях через соответствующие электронные кабинеты; развитие кадастра как основы наџиональной инфраструктуры геопространственных данных. Особое внимание уделено применению научных принцииов в ведении земельного кадастра (завершенности, зеркальности, доверия, страхование, непрерывности, согласия, публичности) с учетом мировых трендов.

Ключевые слова: государственный земельный кадастр, научное обоснование, принциипь, методология ведения земельного кадастра, оиибки, неточности 